\title{
MOURNING AND THE MOVIE SPIRITS' HOMECOMING
}

\author{
Seyon JO, M.A. \\ Kyung Hee University \\ Seoul, South Korea \\ seyonjo@ hotmail.com
}

\begin{abstract}
The movie Spirits' Homecoming connects the past and the present through two Korean "comfort women" and reveals their life, anguish and mourning. Based on Derrida's concept of mourning, this paper analyzes mourning of the main characters and the movie. Furthermore, it focuses on how Korean viewers reacted through mourning presented in Spirits' Homecoming. By doing so, this paper criticizes how the film's vivid representation of "comfort women" reflects patriarchal and nationalist ideologies which position the "comfort women" as the ultimate victims in Korean society.
\end{abstract}

Key words: Mourning, Derrida, (im)possibility, Comfort Women, Nationalism

$$
\text { 영화 〈귀향>과 애도 }
$$

논문초록: 영화 <귀향>은 두 한국인 “위안부” 여성을 통하여 과거와 현재를 연결하며, 그들의 삶과 고뇌, 애도를 그려낸다. 본 논문에서는 데리다의 애도 개념을 바탕으로 주요 등장인물과 영화가 구현하는 애도를 분석하며, <귀향>에서 재현된 애도가 한국인 관객에게 미치는 영향 또한 논하고자 한다. 그 과정에서, 재현된 “위안부”의 이미지에 반영되어 있는 가부장적, 국가주의적 이데올로기가 어떻게 “위안부”를 한국 사회 내 궁극적인 피해자로 위치시키는지 분석하고자 한다.

주제어: 애도, 데리다, (불)가능성, 위안부, 내셔널리즘 


\section{ŻALOBA I CIERPIENIE W FILMIE SPIRITS' HOMECOMING}

Streszczenie: Film Spirits' Homecoming łączy przeszłość i teraźniejszość za pośrednictwem sylwetek dwóch koreańskich kobiet i ujawnia ich życie, udrękę i żałobę. W oparciu o koncepcję żałoby Derridy, niniejszy artykuł analizuje żałobę głównych bohaterek filmu. Co więcej, koncentruje się na tym, jak koreańscy widzowie zareagowali na cierpienie prezentowane w Spirits' Homecoming. Artykuł stanowi także swoistą krytykę sposobu odzwierciedlenia panujących ideologii patriarchatu i nacjonalizmu $\mathrm{w}$ omawianym filmie przy pomocy złożoności problemu kobiet-pocieszycielek. Film bowiem wskazuje przypisany przez wzmiankowane ideologie status kobiet-pocieszycielek jako ofiar.

Słowa kluczowe: żałoba, Derrida, (nie)możność, kobiety-pocieszycielki, nacjonalizm

\section{Introduction}

The movie Spirits' Homecoming, which deals with the issue of "comfort women" " has caused an unprecedented level of controversy in Korea without a doubt; in its opening week, the number of viewers exceeded one million and there was a lot of discussion regarding the movie on Korean websites. Among the discussion, the 'popcorn argument' is worth noting; it was about whether it is permissible to eat popcorn while watching Spirits' Homecoming in the cinema. The argument might seem pointless, still, the discussion was fierce and hot on the net; people protested anyone eating while watching Spirits' Homecoming. I believe this argument is significant,

\footnotetext{
${ }^{1}$ Among scholars and activists, the term "comfort women" and "sexual slaves" are both used to refer to Korean females who were forced into sexual slavery by the imperial Japanese Army during World War II. The compound term ian-fu/wian-bu(Japanese/Korean) reveals the views of a paternalistic state since it referred to an adult female(fu/bu) who provided sexual services to "comfort and entertain"(ian/wian) the soldiers (Soh 69). Since the term does not reflect the perspective of women who were enslaved and conscripted by the army, it is used with the quotation mark. As the "comfort women" issue gained an international attention following a series of United Nations Commission on Human Rights(UNCHR) hearings that began in 1992, the term "comfort women" became interchangeable with "sexual slaves" (Soh 72). Nevertheless, considering the degrading connotation in the term, Koreans still prefer to address the survivor as "comfort women" with the word "grandmother"(halmoni) as a polite form (Soh 72-73).
} 
because it shows the discomfort the Korean population experiences regarding "comfort women".

A similar argument occurred when notable movie critic DongJin Lee gave the score 2 out of 5 for Spirits' Homecoming. Lee only wrote two short phrases as the commentary on the movie: "Resentment over history. Sigh at the movie" (Lee). This in turn has opened a wider debate on Lee and the role of critic: Lee was denounced by the claims that Spirits' Homecoming can not be the object of evaluation and/or critical analysis.

At first glance, Korean audience's sanctification of the movie seems to be caused by two reasons: it is based on Korea's history; and it deals with controversial issues including sexual violence and crime that actually happened in Korea. However, considering that no similar arguments about the attitude of audience and critic occurred regarding movies about the Korean war and history and sex crimes including Silenced (2011) and Han Gong-ju (2013) ${ }^{3}$, it is clear that the sanctification of the movie was caused by other reasons.

To jump to the conclusion, the arguments occurred due to the failure of mourning presented in the movie. This paper will explore the mourning of characters and the movie itself. Moreover, it will analyze patriarchal and nationalist ideologies which position the "comfort women" as the ultimate victims in Korean society.

\section{Mourning of Characters}

In the interview, the Director Jung-Rae Cho, who planned the movie for 14 years, states the movie was made to console and mourn the souls of the victims who could not come back to their homes ${ }^{4}$

\footnotetext{
${ }^{2}$ Lee, Dongjin. Home page. 3 Mar. 2016.

<http://blog.naver.com/lifeisntcool/220644695793>. 29 Nov. 2016. The original resource is written in Korean.

${ }^{3}$ The film Silenced (2011) depicts the sexual abuses that occurred in 2000 at a school for disabled children by the staff and the film Han Gong-ju(2013) deals with the infamous Miryang gang rape case of 2004. Both movie leaded to the self-reflection of Korean society regarding female human right in vulnerable group, however, a nationally sensationalized controversy was not drawn by two movies.

${ }^{4}<$ http://www.gobalnews.com/news/articleView.html?idxno=17653>. The original resource is written in Korean.
} 
(조정래). Withal, it seems dubious whether or not the mourning for the victims was possible through the movie.

It is necessary to understand the concept of Freud's mourning before discussing the concept of Derrida ${ }^{5}$. In "Mourning and Melancholia", Freud analyzes that mourning as "a reaction to the real loss of a loved object" (250). The mourner begins to sever emotional ties to the lost object and eventually completes the work of mourning: To Freud, mourning, "however painful it may be, comes to a spontaneous end" ("On Transience" 307). Therefore, the mourner "must relieve and then relinquish their attachment to the beloved, severing the memories and images that tie them to the dead in order to reconnect to the world of the living" (Kirkby 465).

Nevertheless, to Derrida, Freud's "normal" "work of mourning" (Memoires 34) is an "unjust betrayal" to the lost object because it "entails a movement in which an interiorizing idealization takes in itself" (Memoires 34) and thereby makes the other "a part of the us" (Memoires 35). Thus mourning is the "experience in the form of an aporia" where "success fails" (Memoires 35).

"[T]he other remains foreign in myself, it remains Other, it doesn't become part of myself. I cannot appropriate the other in myself so it is a failure in a work of mourning, but it is the only way of respecting the Otherness of the Other". ... "the only possible way of mourning is "the impossible mourning." (qtd. in Kirkby 466)

Derrida concludes, "mourning is interminable. Inconsolable. Irreconcilable" ("By Force" 143). In this regard, I will discuss the mourning of the characters and search for the possibility of impossible mourning for the issue of "comfort women".

The movie switches the point of view from 1943 to 1991 and reveals the past and present of women drafted by the Japanese military to become "comfort women". The main protagonist of the past is 14 years old Jung-Min. In the 90's, it is Young-Ok(Young-Hee in the past) and Eun-Kyung. A notable point in the movie is that Young-Ok is not the old figure of Jung-Min but Jung-Min's friend, Young-Hee whom Jung-Min saved by sacrificing her life. At the end of the movie,

\footnotetext{
${ }^{5}$ Derrida's texts of mourning including The Work of Mourning and MEMOIRES for Paul de Man reveals Derrida's reserved and critical perspective forms variations of Freud's theories of mourning. ( 786)
} 
Eun-Kyung, as a shaman, performs a traditional Korean ritual and Young-Ok mourns for Jung-Min's death. Through the medium of EunKyung's ritual, Young-Ok confronts Jung-Min and asks Jung-Min's forgiveness for being alive instead of her.

At this point, the confrontation with the dead relies on the supernatural medium through Korea's traditional ritual, Sitgimgut ${ }^{6}$ (씻김굿). During the ritual, the lost object suddenly reappears and intervenes in the relation with the subject. Jung-Min exists in the same space and time with the mourner, Young-Ok. It offers the direct reconciliation with the dead. There is no question that the process of Young-Ok's mourning is impossible mourning in the reality. Still, this impossibility has to be distinguished from Derrida's impossible possibility in true mourning.

Could a subject mourn for 'the other' in front of, and with 'the other'? To Derrida, "even when we speak to the dead simply to ask for their forgiveness, it is often because we do not wish to admit that the dead can no longer respond to us" (Brault and Naas 7). Therefore, it is the denial of both the death and the loss of a mourner. In this respect, the mourning through the ritual not only denies the rationality but also the possibility of mourning; since the deceased Jung-Min returns, she is no longer dead, and cannot be mourned. Therefore Young-Ok's mourning remains only as an impossible mourning of a victim for another victim. It losses the place for dead within us and the possibility of impossible mourning.

As a medium of mourning, Eun-Kyung is a character who also experiences the failure of mourning. Due to the trauma of sexual violence and her father's death, Eun-Kyung closes her mind and left to stay with a Shaman away from her mother. As Eun-Kyung shows the symptoms of autism, she could not perceive her loss; therefore EunKyung is the character that could not even mourn for her father's death. Eun-Kyung lacks the ability to recognize both the life and death of her father. Again, the question returns to the ritual that Eun-Kyung performs: how should we interpret Young-Ok's mourning through Eun-Kyung's ritual if Eun-Kyung herself cannot carry out mourning?

The patriarchal and nationalist ideologies occupy the empty place of possibility for true mourning. For instance, Eun-Kyung's role

\footnotetext{
${ }^{6}$ Sitgimgut is a shamanist ritual for cleaning dead person's soul to rest in Korea. The word Sitgim (씻김) is a noun-form of verb meaning 'cleaning' and gut (굿) is traditional rituals for spirits.
} 
as the link between the past and the present deserves severe criticism. It is impossible to miss the allegorical intention of the director. EunKyung's dead father represents Chosun Dynasty and the rapist/murderer represents the Empire of Japan. Through dreams or temporary moments in reality, Eun-Kyung directly encounters not only the "comfort women" in the past but also the abuse of Japanese soldiers. This setting identifies Eun-Kyung and all the "comfort women" as powerless abused girls. This generalization changes the key point of "comfort women" issue from the violation of basic human right, to the sexual assault on pure girls.

To return to the point, I believe Eun-Kyung's impossible state for mourning implies the failure of mourning of the movie itself. Even though director clearly asserts that the movie was made to console the souls of the victims, it seems like the movie's focus is quite different from the director's intention.

\section{Mourning through the Movie}

More than half of the movie presents the vivid image of violence conducted by the Japanese soldiers. The film provokes the audience's enragement based on male-centered paternalism and nationalism by presenting the "comfort women" as victims of sexual violence from another country, rather than encouraging the chance of mourning for a human being who suffered the war crimes.

For instance, the movie depicts the "comfort women" only as girls and emphasizes their innocent features. Further still, by putting forward the image of a girl, the symbol of purity, as the representation of "comfort women", the film effectively denies the Japanese Government's claim that most of "comfort women" were spontaneous prostitutes who have voluntarily followed the military base during the war.

Nevertheless, this method is only effective since the image of a girl can be interpreted as the opposite of a prostitute. Under the standard that distinguishes girls from prostitutes lies the hidden dichotomy of social bias which evaluates women based on the standard of chastity and sexual purity (최은주 253). The structural violence on a national scale of individuals in colonized countries cannot be justified whether the mobilization of the comfort women 
was voluntary or coercive. However, refuting Japanese government's claim by arguing that they were girls, more precisely virgins, reveals that both countries are not free from the patriarchal nationalistic perspective of objectifying women.

Therefore, the questions remain open for Spirits' Homecoming: whom do we mourn and why do we mourn? Do we mourn for the people who were dehumanized through war crimes and colonialism of Empire of Japan or the death of a girl pictured in the movie? What makes a death of Jung-Min more worthy of grief, while death of Chinese "comfort women" and soldiers remains relatively unnoticed?

As Judith Butler points out in Precarious Life, the national politics and ideology certainly provides "a hierarchy of grief" (20) and distinguishes whose life is grievable. The ideology of a nation only highlights "a publicly grievable life" as "an icon for national selfrecognition" (Butler 34).

[W] have to ask about the conditions under which a grievable life is established and maintained, and through what logic of exclusion, what practice of effacement and denominalization. (Butler 38).

Presenting the issue of "comfort women" as grievable tragedy since they were 'our girls' who were 'taken" from 'us' not only reveal the patriarchal and nationalistic ideology in the society, but also limit the possibility of true mourning.

If the movie only shows how tragic the event was by displaying exploited young bodies, then it only causes pornographic consumption of a tragedy. The background and the afterward of the war should be considered together and exhaustive reflection is required as to how humans actualize the idea of using another human being as a tool, why it was limited only to specific gender and nationality, and how it should be understood and mourned at the present.

However, Spirits' Homecoming does not give any answers to those questions and only offers mourning through supernatural ritual

\footnotetext{
7 It should be noted that the first sentence in the trailer of film is "200K GIRLS TAKEN TO THE COMFORT STATION". Since it clearly groups all "comfort women" as "girls" who were "taken," it triggers questions such as why the victims of "comfort women" have to be referred only as "girls" instead of "Korean" or "Korean female" and why it should be emphasized that they were "taken"?
} 
and resolving individual's grief as a conclusion. The movie intends to mourn for the dead "comfort women," still and all the audience experiences the failure of mourning through the movie.

At the last scene of the movie, the butterflies from the dead bodies of "comfort women" cross the land and return to their hometown ${ }^{8}$. As Psyche means a butterfly and spirit in Greek, this scene literally presents the spirits' homecoming. However, the movie does not just end with the returns of psyche. The audience soon encounters with the ending credit filled with 75,270 names. The names on the ending credit outnumber butterflies and it is even longer than the scene of spirits' return. The names of people and institutions that supported the movie were displayed with the drawn pictures of the survivors. It groups people who have supported the "comfort women" and who have not.

As the movie incarnates severe dichotomy ${ }^{9}$ of $\mathrm{good} / \mathrm{bad}$, innocent/wicked, woman/man, and Korean/Japanese, it affects the audience powerfully and triggers guiltiness and anger based on the nationality. National ideology 'calls' the audience and requests that they be involved in 'us' by showing the list of people that supported 'our' daughters of a nation who lost their purity, which is assumed to be the most important value of women.

Of course, no one can raise an objection to the fact that the Empire of Japan violated the basic human right and committed the war crimes. Nonetheless, if the audience truly experiences mourning through the movie, the rage should be directed toward the imperialism and totalitarianism of the Empire of Japan. However, the criticism targets the Japanese government and people in the present. If we headed for nationalism, it would be impossible to mourn over the victims of the war caused by the Empire of Japan's extreme nationalism.

\footnotetext{
${ }^{8}$ In here, all the individuality disappears and "comfort women" become a single united mass. Individual experience of economic, politic, domestic situation in colonized country is not concerned in the return of spirits. Who can imagine that all the "comfort women" were eager to go back to the colonized nation and patriarchal society which regarded them as a national disgrace?

${ }^{9}$ Although the movie does not fear to present a good Japanese soldier, even so, he soon get murdered for not following the military order to kill the "comfort women." Paradoxically, the group of Japanese soldier remains as the bad group which a good Japanese individual can not survive and dichotomous standard dividing Korea/Japan and victim/murderer became stronger.
} 
Director Cho states that Spirits' Homecoming was made by the idea that the dead "comfort women""s spirits would return every time the movie was screened and it contains a desperate longing for a world without war. The director also adds that he didn't want to simply denunciate Japan or dare to console the anguish of survivors $^{10}$ (김용만). That is why the movie should not conclude with anti-Japan sentiment, even though it is hard to not feel the animosity toward Japan after watching the film.

\section{Possibility of Mourning}

The surviving "comfort women" have protested for a sincere apology from the Japanese government for decades and they are witnesses of history and Japanese war crimes. They are the subjects who work as activists for women's right and anti-violence even at this moment. Therefore, it is not appropriate to frame them as the objects of unconditional mourning or vulnerable daughters of a nation. In this regard, the term "comfort women grandmother" should not be used. The collective appellation of survivors as our grandmothers "obscures their individual personhood" and "ignores their diverse social backgrounds prior to their mobilization as comfort women, and their disparate postwar life stories" (Soh 76).

In this respect, the only significant scene through out the movie is when Young-Ok cries out, "I am that crazy woman. "11 Young-Ok defines herself as the surviving "comfort woman" in the community service center and positions herself as the individual subject, not as the ineffective and silenced victims.

A Japanese scholar, Chizuko Ueno argues that the testimonials of "comfort women" are shocking for two reasons: the cruelty of issue in real history and the society's long silence on the issue which lasted for 50 years from the war (우에노 99). It is also notable that most of comfort women issue were interpreted from the

\footnotetext{
${ }^{10}<$ http://star.ohmynews.com/NWS_Web/OhmyStar/at_pg.aspx?CNTN_CD=A00021 84754>. The original resource is written in Korean.

${ }^{11}$ Young-Ok visits the community center to report herself as a survivor of "comfort women." While hesitating, she overheard the conversation between the staff arguing "it is crazy to report oneself as comfort women."
} 
Korean male perspective and regarded as a disgrace for the nation. Young-Ok's crying reveals her desperate effort to be positioned as "subject" and to escape from the position of "victim" fixed by Korean patriarchal ideology.

If the movie sincerely desired to mourn for the victims of national ideology of Empire of Japan, it should have paid more attention to the portrayals of individuals as a subject and their eternal mourning rather than focusing on grouping all "comfort women" as powerless young girls or 'our' grandmother.

The 'Statue of Peace'(the Comfort Woman Statue) might offer breakthrough to the failure of mourning presented in the movie. The monument was erected on the 1000th weekly demonstration; the surviving "comfort women," civic groups, and individuals have been holding the 'Wednesday Demonstration' in front of the Japanese embassy in Korea since 1992. On the shoulders of a statue, a bird lies which represents peace and freedom and on the chest there is a butterfly symbolizing the reincarnation. The empty chair next to the statue signifies the spirits of "comfort women" who have passed away (최은주 244-45).

Even though this statue was also criticized for representing "comfort women" only as girls and the underlying dichotomy of distinguishing women, this paper will focus on the empty chair and the gaze of a statue, not the representation of figure. The statue of chair next to a girl is not just a chair, it is always interpreted as an empty chair without the sitter. The emptiness of a chair directly reveals the absence of a person's presence. This person can not be named or identified, since the chair does not tell anything about a sitter. However, we see the emptiness through the chair, and we know that something has gone, disappeared and lost, without even knowing what it is.

We may be able to imagine what she/he would be and how she/he has lived but it will always fail, since the presented emptiness rejects to be identified, it remains only as the image of death. Can we mourn for someone who we know nothing of and share no personal memory while avoiding a hierarchy of grief provided by national politics and ideology? It might not be possible, but in impossible mourning of Derrida, it might be.

[T] he being-to-death of an image that has the force that is nothing other than the force, to resist, to consist, and to exist in death, precisely there 
where it does not insist in being or in the presence of being. This being-todeath would oblige us to think the image not as the weakened reproduction of what it would imitate, ... but as the increase of power, the origin, in truth, of authority, ... in the image of the dead. ("By Force" 147)

The statue of an empty chair carries the powerful force which insists to remain as something unknown and unnamable other, as an image of being the dead.

Moreover, this emptiness emphasizes the presence of a figure and its gaze. Without any facial expression, the statue is sitting on the chair while gazing forward; it is not a mere object for our gaze. It gazes toward us. The gaze of an image, as Derrida has argued, it is not just the indication of "a mere rhetorical commonplace" ("By Force" 161).

The one who looks at us in us--and for whom we are--is no longer; he is completely other, infinitely other, ... This gaze is his, and it will always remain his, infinitely; it comes from him singularly, from him alone, ... Far away in us. In us, there where this power of the image comes to open the being-far-away. This excess also brings about the limitless enlargement of the image. Its power of dilation gives it its greatest force in the mourning of the absolute of "force." ("By Force" 161)

This gaze of the statue assigns us the force of the mourning. As Derrida's model of mourning is "an ongoing conversation with the dead" who continues to look at us, the look of a dead is "a call to responsibility and transformation" (Kirkby 461). We hold the responsibility for the other, for the dead, and for the "comfort women" to speak to us from far-away within us. The mourning may be possible not through the enragement provoked by nationalism in the movie, but by facing the gaze of a statue, sitting on the empty chair next to it, and trying impossible mourning for someone whose name and face remains unknown as the infinite other.

\section{Bibliography}

Brault, Pascale-Anne, and Michael Naas, eds. 2001. Editor's Introduction. The Work of Mourning. Chicago: UP of Chicago. 
Butler, Judith. 2004. Precarious Life: the Powers of Mourning and Violence. London and New York: Verso.

Derrida, Jacques. 1989, Memoires: for Paul De Man. Trans. Cecile Lindsay. New York: Columbia UP.

Derrida, Jacques. 2001. "By Force of Mourning." The Work of Mourning. Eds. Pascale-Anne Brault and Michael Naas. Chicago: UP of Chicago. 139-164.

Freud, Sigmund. 1957. "Mourning and Melancholia." On the History of the Psycho-Analytic Movement: Papers on Metapsychology and Other Works. Ed. James Strachey. London: Hogarth Press. 243-58.

Freud, Sigmund. 1957. "On Transience." On the History of the Psycho-Analytic Movement: Papers on Metapsychology and Other Works. Ed. James Strachey. London: Hogarth Press. 305-307.

Kirkby, John. 2006. "Remembrance of the Future": Derrida on Mourning." Social Semiotics 16.3: 461-73.

Soh, C. 2008. Sarah. The Comfort Women. London: UP of Chicago. 김용만. 2016. 「영화〈귀향>, 돌아오지 못한 넚을 위로하다」. 『오마이뉴스』.

<http://star.ohmynews.com/NWS_Web/OhmyStar/at_pg.aspx ?CNTN_CD=A0002184754>. 2016.2. 25.

왕철. 2012. 「프로이트와 데리다의 애도이론:-"나는 애도한다 따라서 나는 존재한다”」.『영어영문학』 58.4: 783-807. 우에노 지즈코. 2012.『위안부를 둘러싼 기억의 정치학』. 이선이 옮김. 서울: 현실문화.

조정래. 2016. 이영광 인터뷰.「'태워지는 처녀들' 장면, 울며 찍는데 나비 한 마리가 날아왔다”」.『고발뉴스』. $<$ http://www.gobalnews.com/news/articleView.html?idxno=1 7653>. 2016.3.21.

최은주. 2016. 「위안부= ‘소녀'상과 젠더」.『동아시아문화연구』 66: 243-62. 